\title{
Reporting detailed information and acknowledging donor-cadavers: good practice recommendation for anatomists
}

\author{
İlke Ali Gürses, Esranur Korkmaz, Adnan Öztürk \\ Department of Anatomy, Istanbul Faculty of Medicine, Istanbul University, Istanbul, Turkey
}

\begin{abstract}
Objectives: In order to facilitate a healthy and trusting relationship between anatomists and their society, appreciating the anatomical gift of the individuals that donated their bodies to science in every way possible remains central. Apart from memorial services and monuments, scientific articles themselves can be a good platform to show this appreciation. In this article, we aimed to an create and awareness among anatomists and researchers by evaluating the information given regarding donor-cadavers in their articles and see if they acknowledged them.

Methods: We evaluated all articles that used human cadaveric specimens by Turkish anatomists published between January 2011 and April 2016 and assessed if researchers provided data on the age, gender, preservation technique(s), source, and ethical / legal permissions regarding the cadavers used.

Results: Majority of the articles provided data about gender (74.5\%) and age (68.9\%). Preservation technique (56.6\%) and source of specimens (50.5\%) were reported less frequently. While $28.3 \%$ of the articles provided data on some form of ethical approval, only $11.8 \%$ of the articles provided data on the consent of the individuals. Ten (4.7\%) articles acknowledged the cadavers and/or their families.

Conclusion: We believe it is the duty of anatomists to promote body donation within their society by building a trustworthy relationship. Scientific articles that depend on donor-cadavers should also be used to promote this relationship. Therefore, awareness among anatomists should be raised to discuss ethical grounds for scientific research on cadavers.
\end{abstract}

Keywords: anatomy; cadaver; guideline; medical ethics; research

Anatomy 2016;10(3):177-181 @2016 Turkish Society of Anatomy and Clinical Anatomy (TSACA)

\section{Introduction}

Cadavers are essential for medical education and research. ${ }^{[1,2]}$ Despite their importance, dissection courses sometimes traumatize the students and result in materialization of the cadavers to form a level of detachment. ${ }^{[3,4]}$ Additionally, majority of scientific journals use the term "material(s)" to define the cadavers and forget that they were once individuals. ${ }^{[5]}$ It is important for the anatomists and related researchers to form a healthy and trustworthy relationship with the society which is the source of their specimens for future research and continuous medical education. There are a few options available for maintaining this relationship; reflection practices and commemoration services ${ }^{[6,7]}$ recorded donor interviews, ${ }^{[8]}$ de-anonymization of donor-cadavers, ${ }^{[9]}$ and donor monuments ${ }^{[10]}$ are good opportunities for future doctors to emphasize with the donor-cadavers and their relatives. These practices create a reciprocal appreciation between the anatomists and the community they live in. Another supportive way expressing appreciation is the actual work that depends on the gifts of donor-cadavers i.e. the scientific articles. Providing detailed information regarding the donor-cadavers including demographics, preservation methods, source of specimens, formal approvals, and donors' consent in articles is not only important for the repeatability of the work, but also essential to emphasize that human cadavers are treated with respect and dignity just like a living person rather than freely accessible materials with limited rights bestowed by whomever claims them.

A few recent studies have evaluated the amount of information provided in articles published in orthopaedics and anatomy journals in order to create an awareness 
among scientific community. ${ }^{[5,11]}$ These studies showed that there was not a standard way of reporting information and some information (source, formal approval, and consent) were mostly neglected by researchers.

In this study, we aimed to investigate the amount of information provided in the articles authored or coauthored by Turkish anatomists that used human cadaveric specimens. We also aimed to see how common do anatomists acknowledge the gift of their donor-cadavers and/or their families. Lastly, we aimed to create an awareness regarding the value of donor-cadavers among Turkish researchers who use human cadaveric materials in their studies.

\section{Materials and Methods}

We performed an electronic search on Google Scholar ${ }^{[12]}$ to find all articles that were authored or co-authored by Turkish anatomists from medical and dental schools. The time filter was set between January 2011 and April 2016. We evaluated articles published in international journals indexed and not indexed in Science Citation Index and Science Citation Index-Expanded. Articles published in national journals indexed in TÜBİTAK ULAKBİM database were also included. We included articles that used tissues, organs, and bodies of deceased individuals, infants, and fetuses with different gestational stages. Review articles, educational studies that did not use cadaveric specimens, surgical and radiologic studies performed on patients, studies performed on surgical excision specimens, and pre-existing osteological collections were excluded from the study. For avoiding iteration, we cross-checked authors and titles of every article and excluded repeating studies. Articles that were published online, but not printed as of April 2016 were also excluded.
First, the demographic (age and gender) and technical (preservation) data provided in the articles regarding the donor-cadavers were evaluated. We accepted the source of specimens as any institution that provided the specimens. The terms that implied consent of the donor-cadavers including "written consent", "donor", "donation", "donated", "bequest", "bequeath", and "bequeathal" were evaluated, and if any information was provided about the ethical or formal approval for the study, this was noted. Finally, we determined if the authors acknowledged the donor-cadavers and/or their families as proposed previously. ${ }^{[13]}$

\section{Results}

Table 1 summarizes our results and comparison with previous studies. We evaluated 375 authors from 85 institutions. Two hundred and twelve articles met our inclusion criteria. The majority of articles $(158,74.5 \%)$ provided information regarding gender. Ninety-nine (46.7\%) articles provided the age of the specimens as mean and 47 $(22.2 \%)$ articles as range.

We found that $120(56.6 \%)$ articles provided information about the preservation technique. Only 5 articles mentioned more than one method. The techniques used included embalming with a specific method in $96(45.3 \%)$, embalming with an unspecified method in $9(4.2 \%)$, fresh in $12(5.6 \%)$, fresh-frozen in $7(3.3 \%)$, and plastination in $1(0.5 \%)$ articles.

Only 107 (50.5\%) articles reported the source of the specimens. Two articles reported more than one source for the specimens used. The source of the specimens was anatomy departments in 97 (45.7\%), the Forensic Institution of the Ministry of Justice in 10 (4.7\%), and an institution in $2(0.9 \%)$ articles.

Table 1

Information provided in articles authored by Turkish anatomists compared with previous studies.

\begin{tabular}{|c|c|c|c|c|c|c|}
\hline & \multicolumn{2}{|c|}{ Present study } & \multicolumn{2}{|c|}{ Gürses et al. ${ }^{[11]}$} & \multicolumn{2}{|c|}{ Winkelmann et al. ${ }^{[5]}$} \\
\hline & $\mathbf{n}$ & $\%$ & $\mathbf{n}$ & $\%$ & $\mathbf{n}$ & $\%$ \\
\hline Total number of articles investigated & 212 & 100 & 586 & 100 & 345 & 100 \\
\hline \multicolumn{7}{|c|}{ Number of articles reporting information regarding } \\
\hline Age & 146 & 68.9 & 405 & 69.1 & 260 & 75 \\
\hline Gender & 158 & 74.5 & 425 & 72.5 & 196 & 57 \\
\hline Preservation method & 120 & 56.6 & 426 & 72.7 & 295 & 86 \\
\hline Source of specimens & 107 & 50.5 & 319 & 54.4 & 78 & 23 \\
\hline Consent & 25 & 11.8 & 154 & 26.3 & 139 & 40 \\
\hline Formal approval & 60 & 28.3 & 190 & 32.4 & 58 & 17 \\
\hline Acknowledgment for donors / family & 10 & 4.7 & 104 & 17.7 & 2 & 0.6 \\
\hline
\end{tabular}


Some form of ethical approval was reported in 60 $(28.8 \%)$ articles. In 51 (24\%) articles institutional review board was obtained, $8(3.8 \%)$ articles complied with institutional guidelines, and $1(0.5 \%)$ article conformed state legislations. Among the 51 studies that obtained ethical approval, 30 were performed on fetal and 21 on adult cadavers. Studies that obtained Institutional Review Board for Protection of Human Subjects (IRB) approval were performed in 18 different institutions.

We found that $25(11.8 \%)$ articles mentioned a degree of consent of the donor-cadavers. In $19(9 \%)$ articles written consent was obtained and in $6(2.8 \%)$ articles terms implying a donation was used. One hundred eighty seven $(88.2 \%)$ articles did not provide information on the consent of the cadavers.

The authors acknowledged the donor-cadavers and their families in $10(4.7 \%)$ articles. Figure 1 shows the number of acknowledgements per year.

\section{Discussion}

We found that Turkish Anatomists were similar to their colleagues worldwide for reporting demographic information regarding cadaveric specimens (Table 1). $)^{[5,11]}$ Researchers from the field of orthopedics reported the age of the cadavers more often $(75 \%$ vs. $68.9 \%$ for Turkish anatomists and $69.1 \%$ for international anatomists). Anatomists, on the other hand, reported information on gender with a higher frequency $(74.5 \%$ for Turkish anatomists and $72.5 \%$ for international anatomists vs. $57 \%$ ) (Table 1). The reason(s) for not reporting demographics remains unclear. It is possible, either the researchers have omitted the information that they see irrelevant to the study at hand, or the information was not available. While the former is unacceptable, the latter is debatable. The unavailability of information may be due to the use of unclaimed cadavers or a legal limitation. For example in France, the Civil Code which regulates body donation also entails complete anonymity of the donors as well. ${ }^{[14]}$ Therefore, the information remains unavailable for most researchers. Nevertheless, reporting demographics of donor-cadavers in research articles is a must for scientific methodology and should be promoted whenever possible. If not, authors should mention the reasons for not reporting this information.

Articles from musculoskeletal researchers surprisingly reported their preservation method more often compared to anatomists $(86 \%$ vs. $56.6 \%$ for Turkish anatomists and $73.2 \%$ for international anatomists). ${ }^{[5,11]}$ We found that nearly half of Turkish anatomists did not mention a preservation method as if they took this step of their research for granted. Although the reasons for this inade- quacy is a topic for further research, reporting detailed methodology including embalming or preservation methods should be promoted by national associations and journal editors. It should be kept in mind that describing the steps of methodology is essential for comparing and repeating the study data. Therefore, skipping this step may be considered as inadequate reporting of study design and methodology.

Turkish anatomists reported the source of the specimens they used in a similar way with their international colleagues. ${ }^{[1]]}$ Although it is important to report the source of specimens for maintaining a healthy relationship with their society, the authors may not have neglected this information intentionally. The authors may have chosen to remove this information in order to blind the manuscript for submission processes or to accord word count limits of the journals. Not reporting the source is a serious topic. This may give public the opinion that the specimens used are freely available, which is not the case in majority of the world. As suggested previously, the authors either take available cadavers for granted or just consider this unnecessary. A new reason behind this may be the foreign source of cadavers. Not-for-profit and for-profit companies are usual sources of cadavers in North American countries. ${ }^{[2,5]}$ Within the last couple of years, some European countries have started to import foreign cadavers with high costs. Bodies imported from the USA are used at private training centers in Italy. ${ }^{[15]}$ Similarly, a

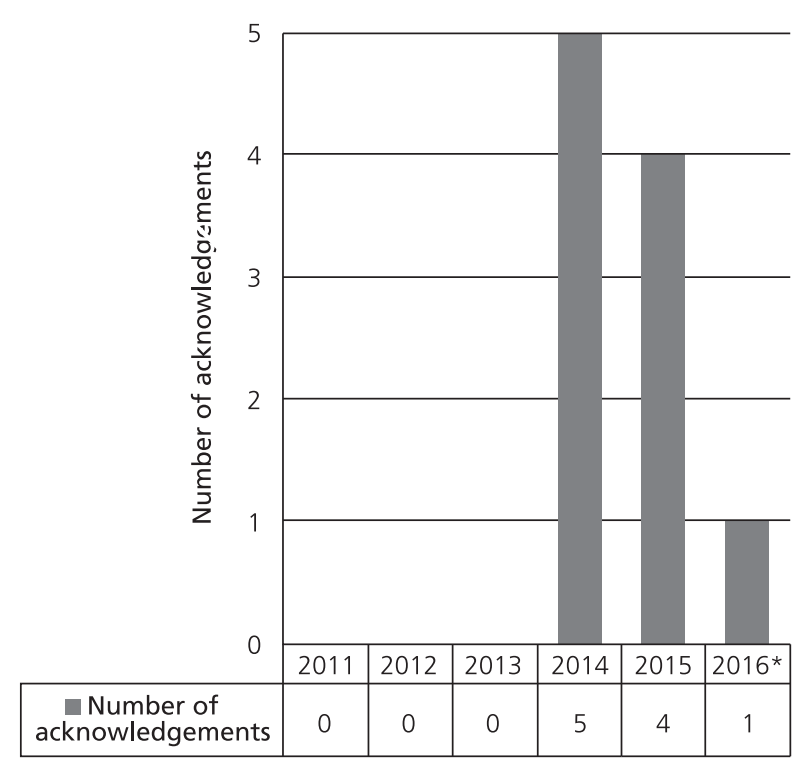

*Note that acknowledgements for 2016 are from January to April.

Figure 1. Number of donor-cadaver acknowledgements by Turkish anatomists per year. 
recent editing to the related Law (No: 2238) in 2014 allowed Turkish institutions to import cadavers from the USA and China. ${ }^{[16-20]}$ This practice has a few major problems. In Turkey, body donation is still a taboo and importing cadavers may end up alienating the society from the idea of body donation itself. Secondly, the consent of the imported cadavers remains uncertain. The companies do not provide that the consent of the donors included the transport and use of their bodies in foreign countries. Additionally, any profit based practice has a risk of labeling human bodies or body parts as disposable property. ${ }^{[21]}$ Nevertheless, it is important to report the source of cadaveric specimens to avoid giving a false impression that human cadaveric material is easy to acquire and use.

Nearly one third of Turkish anatomists provided some form of ethical approval for their studies. This rate is similar to the rate of international anatomical community. ${ }^{[1]]}$ Applying and reporting ethical approval for studies performed on human cadaveric specimens is an ongoing debate. For example in Turkey, procurement of human bodies is governed with a legislation (No: 2238) and its related regulation. ${ }^{[16,22]}$ Although a legislation is present that regulates procurement of human bodies for education and research, our results show that practices regarding ethical approval for cadaveric studies remain uncertain in Turkey. We found that 51 studies have already obtained IRB approval for cadaveric studies. We also found that fetal cadaveric studies were more likely to apply for a formal ethical approval ( $n=30$ vs. $n=21$ ). It is apparent that practices among institutional review boards within different institutions differ in Turkey. For example, both boards of two medical faculties at Istanbul University request IRB approval for studies performed on human cadavers and skeletons since January 2016. Same situation is present for The Scientific and Technological Research Council of Turkey (TÜBİTAK) and Bezmialem University. ${ }^{[23,24]}$ This dispute roots from the ethical status of cadavers which previously showed that it was not the same as living human beings under current legal and ethical framework. ${ }^{[5,25]}$ Despite this lack of framework, every cadaver (donated or not) deserves respect until the final disposition of the body. ${ }^{[26,27]}$ From this point of view, Winkelmann et al. ${ }^{[5]}$ argued that an IRB application would set the cadavers' status as of a living individual, thus making it possible for the society to perceive this as showing respect to the cadavers and reinforcing the notion of body donation.

Articles authored by Turkish anatomists were less likely to report the consent of cadavers compared to articles published in international anatomy and orthopaedic journals. ${ }^{[5,11]}$ It is not clear whether the authors choose not to provide this information or refrained from something else. Gürses et al. ${ }^{[1]}$ argued that researchers who used unclaimed bodies may have hesitated in order to avoid unwanted ethical disputes during peer-review process of articles. Although most Western scientists consider using unclaimed bodies for medical research as dubious, ${ }^{[28]}$ this practice is still the major body procurement method for many countries where donation is infrequent or absent. ${ }^{[15]}$ In Turkey, despite the inception of a nation-wide donation campaign ${ }^{[29]}$ and a few news reports ${ }^{[18,30]}$ pointing out the dire situation, donations remain exceptional. One should hope this situation is transitional and body donation becomes the only way of body procurement gradually.

We found that $4.7 \%$ of the articles acknowledged their cadavers and their families starting from 2014. Although this rate is lower when compared to international anatomical community, it is still heart-warming to see researchers appreciating the contributions of donor-cadavers to their work. The cadavers used in research studies may not fulfill the requirements for authorship, ${ }^{[3]}$ but their contribution to the study should not go unnoticed as well. Acknowledging is a sincere way to honor any individual who contributed to a given study. Therefore, acknowledging donor-cadavers and their families in anatomical research articles is a healthy way of showing appreciation and also empowers the relationship of trust between the anatomists and the society that they depend on future research. Gürses et al. ${ }^{[1]}$ proposed that this method of appreciation should be promoted and remain voluntary as well.

There were a few limitations in our study. Firstly, we did not investigate if single-center studies reported the source or not. We also accepted first author's institution as the place of research. By doing so, we neglected multicenter studies and authors with more than one affiliation.

\section{Conclusion}

As proposed earlier ${ }^{[j]}$ a standard order for reporting information regarding human cadaveric specimens needs to be established. This standard reporting should include the age, gender, preservation/research method(s), and the source of specimens without exception. It is important to report the information regarding consent, but using unclaimed bodies should not be set as an obstacle without considering the country of research and its cultural background for body donation. Since Turkish legislations do not provide a framework for ethical approval for cadaveric studies and institutional practices differ, it is up to the researchers to apply for institutional review board approval. Finally, without doubt, every anatomist and researcher who appreciates the contribution of their society by acknowledging cadavers (donor or not) and their families should be promoted. 


\section{References}

1. Dyer GSM, Thorndike EL. Quidne mortui vivos docent? The evolving purpose of human dissection in medical education. Acad Med 2000;75:969-70.

2. Winkelmann A. Anatomical dissection as a teaching method in medical school: a review of the evidence. Med Educ 2007;41:15-22.

3. Hildebrandt $\mathrm{S}$. What is happening in our anatomical dissection rooms? Clin Anat 2014;27:833-4.

4. Lemmp HK. Perceptions of dissection by students in one medical school: beyond learning about anatomy. A qualitative study. Med Educ 2005;39:318-25.

5. Winkelmann A, Heinze AK, Hendrix S. Acknowledging tissue donation: human cadaveric specimens in musculoskeletal research. Clin Anat 2016;29:65-9.

6. Jones TW, Lachman N, Pawlina W. Honoring our donors: a survey of memorial ceremonies in United States anatomy programs. Anat Sci Educ 2013;7:219-23.

7. Subasinghe SK, Jones DG. Human body donation programs in Sri Lanka: Buddhist perspectives. Anat Sci Educ 2015;8:484-9.

8. Bohl M, Holman A, Mueller DA, Gruppen LD, Hildebrandt S. The willed body donor interview project: medical student and donor expectations. Anat Sci Educ 2012;6:90-100.

9. Talarico EF. A change in paradigm: giving back identity to donors in the anatomy laboratory. Clin Anat 2013;26:161-72.

10. Bolt S. Bodies does matter: Gift giving and the unveiling of body donor monuments in the Netherlands. Med Anthropol Q 2012;26: 613-34.

11. Gürses İA, Coşkun O, Gürtekin B, Kale A. The amount of information provided in articles published in Clinical Anatomy and Surgical and Radiologic Anatomy regarding human cadaveric materials and trends in acknowledging donors/cadavers. Surg Radiol Anat 2016;8: $1225-31$.

12. Google Scholar [database on the Internet]. Mountain View (CA): c2004 Google Inc; [cited 2016, Apr 20]. Available from: http://www. scholar.google.com

13. Benninger B. Formally acknowledging donor-cadaver-patients in the basic and clinical science research arena. Clin Anat 2013;26:810-3.

14. McHanwell S, Brenner E, Chirculescu ARM, Drukker J, van Mameren H, Mazzotti G, Pais D, Paulsen F, Plaisant O, Caillaud MM, Laforet E, Riedere BM, Sanudo JR, Bueno-Lopez JL, DonateOliver F, Sprumont P, Teofilovski-Parapid G, Moxham BJ. The legal and ethical framework governing body donation in Europe - A review of current practice and recommendations for good practice. Eur J Anat 2008;12:1-24.

15. Riederer BM. Body donations today and tomorrow: what is best practice and why? Clin Anat 2016;29:11-8.

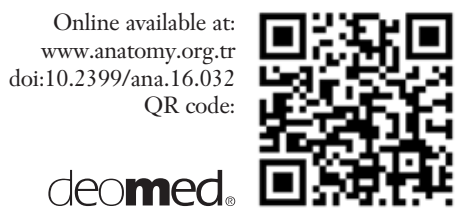

16. Organ ve doku alınması, saklanması, aşılanması ve nakli hakkında kanun. Kanun numarasi: 2238. http://www.mevzuat.gov.tr/Mevzuat Metin/1.5.2238.pdf Accessed 20 April 2016

17. Sağlık Bakanlığı ve bağlı kuruluşların teşkilat ve görevleri hakkında kanun hükmünde karaname ile bazı kanunlarda değişiklik yapilmasina dair kanun. http://www.resmigazete.gov.tr/eskiler/ 2014/01/20140118.pdf Accessed 20 April 2016

18. Çubukçu B. Kadavrasız anatomi dersi. Al Jazeera Turk 09 February 2016 http://www.aljazeera.com.tr/al-jazeera-ozel/kadavrasiz-anatomidersi Accessed 20 April 2016

19. Hürriyet. Doktor adaylarına ithal kadavra. Hürriyet Kelebek. 23 January 2016 http://www.hurriyet.com.tr/doktor-adaylarina-ithalkadavra-40044207 Accessed 20 April 2016

20. Sözcü. Çin'den kadavra ithal edeceğiz. Sözcü Gazetesi. 28 April 2015. http://www.sozcu.com.tr/2015/gundem/cinden-kadavra-ithaledecegiz-816673/ Accessed 20 April 2016

21. Champney TH. The business of bodies: ethical perspectives on forprofit body donation companies. Clin Anat 2016;29:25-9

22. İnsan cesedi üzerinde bilimsel araştırma yapılmasına ilişkin yönetmelik. http://www.resmigazete.gov.tr/main.aspx?home=http://www resmigazete.gov.tr/arsiv/17727.pdf\&main=http://www.resmigazete. gov.tr/arsiv/17727.pdf Accessed 20 April 2016

23. TÜBİTAK. Etik kurul onay belgesi bilgi notu. Temmuz 2014. http://tubitak.gov.tr/sites/default/files/etik_onay_bilgi_notu_23_07_ 13.pdf Accessed 22 December 2016

24. Bezmialem Vakıf Üniversitesi Sağlık Bilimleri Enstitüsü. Etik kurul yönlendirme şeması. http://sbe.bezmialem.edu.tr/Documents/BVU_ Etik_Kurul_Yonlendirme_Semasi-r.pdf Accessed 22 December 2016

25. Champney TH. A proposal for a policy on the ethical care and use of cadavers and their tissues. Anat Sci Educ 2011;4:49-52.

26. International Federation of Associations of Anatomists. (2012) Recommendations of good practice for the donation and study of human bodies and tissues for anatomical examination. Plexus January 2012:4-5. http://ifaa.net/index.php/plexus/finish/3-plexus/3-plexus2012/0 Accessed 20 April 2016

27. Jones DG. Searching for good practice recommendations on body donation across diverse cultures. Clin Anat 2016;29:55-9.

28. Jones DG, Whitaker MI. Anatomy's use of unclaimed bodies: Reasons against continued dependence on an ethically dubious practice. Clin Anat 2012;25:246-54.

29. Turkish Society of Anatomy and Clinical Anatomy. Ulusal Anatomi Haftası Basın Bildirgesi 2012 http://www.anatomidernegi.org.tr/ kadavra-bagisi-ve-temini Accessed 20 April 2016

30. Erenoğlu C. Herkes onu konuşuyor! HaberTürk Pazar 02.09.2012 http://www.haberturk.com/saglik/haber/772940-herkes-onukonusuyor Accessed 20 April 2016

31. Defining the role of authors and contributions [homepage on the Internet]. Philadelphia: c2015 International Committee of Medical Journal Editors; [updated 2006 May 26; cited 2016 Apr 20]. Available from: http://www.icmje.org. Accessed 20 April 2016
Correspondence to: Esranur Korkmaz, MD

Department of Anatomy, Istanbul Faculty of Medicine,

Istanbul University, Istanbul, Turkey

Phone: +90 2124142176

e-mail: dresranurkorkmaz@gmail.com

Conflict of interest statement: No conflicts declared.

This is an open access article distributed under the terms of the Creative Commons Attribution-NonCommercial-NoDerivs 3.0 Unported (CC BY-NCND3.0) Licence (http://creativecommons.org/licenses/by-nc-nd/3.0/) which permits unrestricted noncommercial use, distribution, and reproduction in any medium, provided the original work is properly cited. Please cite this article as: Gürses İA, Korkmaz E, Öztürk A. Reporting detailed information and acknowledging donor-cadavers: good practice recommendation for anatomists. Anatomy 2016;10(3):177-181. 